African J. Biol. Sci., 15 (1): 235-252 (2019)

ISSN 1687-4870

www.ajbs.journals.ekb.eg

\author{
e- ISSN 2314-5501 (online) \\ e.mail: aasdjournal@yahoo.com
}

\title{
Chemical and functional properties of free-gluten biscuit making from corn, quinoa and millet flours
}

\author{
Samah M. Ismael ${ }^{1}$, Sahar S. A. Soltan ${ }^{2}$, Hoda, M. H. Ahmed ${ }^{2}$, Reda A. Mohamed ${ }^{1}$ and \\ Mahmoud A.El-Wakeel ${ }^{3}$ \\ 1- Home Economic Dept., Faculty of Specific Education, Ain Shams Univ., Cairo, Egypt \\ 2- Home Economic Dept., Faculty of Specific Education, Fayoum Univ., Fayoum, Egypt \\ 3- Food science Dept., Faculty of Agriculture, Bani-Suef Univ., Bani-Suef 62511, Egypt
}

\begin{abstract}
The present study was carried out to evaluate the chemical and functional properties of gluten-free biscuit formulation and their relation to final product quality making from different ratios of corn, quinoa and millet flours. The result showed that quinoa seeds contained acceptable range of saponin. Washing and soaking processes succeeded to reduce saponin content from $0.035 \%$ to $0.022 \%$. Corn flour had higher percentage of moisture $(6.86 \%)$ than quinoa $(5.41 \%)$ and millet $(4.87 \%)$. The highest percentage of fat was $9.72 \%$ in corn followed by millet $7.9 \%$ and quinoa $6.55 \%$. Quinoa and millet are worthy of consideration as an important grain source of protein being 15.10 and $12.50 \%$ in dry matter, respectively, while it was $9.20 \%$ in corn. Millet and quinoa had high percentage of crude fibers (4.28\% and $3.94 \%$, respectively) as compared to corn (2.76\%). Starch content as an important part in carbohydrate was $41.29 \%$ in corn, $46.97 \%$ in quinoa, and $43.85 \%$ in millet.

Millet generally contains significant amounts of essential amino acids particularly the sulphur containing amino acids methionnine and cycsteine (2.87 and 3.60, respectively) compared to quinoa and corn. Quinoa is a good source of minerals iron (4.47), calcium (82.78), magnesium (169.55) and potassium (1508.64 mg/100g). Vitamins soluble in fat (Vit. A and Vit. E) were found to be the highest ratio in corn followed by quinoa then millet.

Results also revealed that water holding capacity (WHC) was increased in (quinoa+corn) followed by millet. Corn with millet and quinoa increased wettability actions while, quinoa + millet recorded the lowest values. Also, increasing the level of corn flour increased sensory scores of biscuits for over all acceptability as seen in blended (25\% $\mathrm{Q}+75 \%$ corn) followed by $(75 \% \mathrm{Q}+25 \% \mathrm{C})$ and it was $74.3 \pm 9.6$ and $71.4 \pm 8.6$ respectively. Whereas, control biscuit $(100 \%$ corn) sample had the highest value in all parameters and over all acceptability was (87.2 \pm 9.8$)$ compared to other tested samples. In conclusion, addition of corn flour by each ratio to quinoa or millet recorded good values and satisfied acceptable about blended the three samples with each other.
\end{abstract}

Keywords: Corn, Quinoa, Millet, Biscuit, Free Gluten, Composite Flours, Functional Properties.

\section{INTRODUCTION}

Corn is considered as one of the major cultivated crops in Egypt. Its production is increasing steadily. However, the majority of the crop production is directed for animal and poultry feeding, in spite of the shortage in the cereal-based food stuffs. Therefore, it would be beneficial to introduce new manufactured corn products to the Egyptian food market such as Tortillas. In the last decade the volatility of corn prices, consequence of a continuous increase in biofuels production as well as oil price rise and speculation (Ajanovic, 2011), 
Samah M. Ismael et al.

has caused the increase in the production. The future of this crop is bright because it is environmentally more flexible than other cereals and shows better tolerance to diseases, drought, and pests than its parental species costs of nixtamalized corn flour (Darvey et al., 2000).

Quinoa (Chenopodium quinoa Willd) has added popularity worldwide appreciations to the attractive nutritional profile. Starch is the major component of quinoa grain and makes up to $70 \%$ of the dry matter. The starch acting a vital role in functional properties of quinoa and associated food products (Zhu and $\mathrm{Li}, 2018$ ). The flours obtained from quinoa seeds, can be used for elaborated bread or biscuits. Nowadays, in the shop, diverse products with a 20\% content of quinoa are commercially available i.e., backed products, infant foods, and gluten free products (Pellegrini and Agostoni, 2015; Wang and Zhu, 2016). Furthermore, the gluten-free kind of quinoa seeds makes to this pseudocereal a valued dietary source of digestible protein for persons with gluten sensitivity and coeliac disease (Tang et al., 2015). This wide range of use quinoa seeds due to its versatility as food component, representing an motivating field of research due to the high content of different macromolecules and phyto-chemicals content in their seeds (Gordillo-Bastidas $e t$ al., 2016). This pseudocereal holds more biological value proteins and bioavailable essential amino acids, dietary fiber, unsaturated lipids, complex carbohydrates and other beneficial bioactive compounds such as polyphenolic compounds resulting in enormous helpful health properties to customers (Wu, 2015; Fischer et al., 2017). These substances have already presented diverse in vitro biological potentials (Gawlik-Dziki et al., 2013) and in vivo activities against various diseases and metabolic conditions (Graf et al., 2015; Gordillo-Bastidas et al., 2016).

Millets are one of the cereals asides the other major cereal crops in Egypt such as wheat, rice, and maize. Millets are major food sources for millions of people, especially those who live in hot, dry areas of the world because of their ability to grow under hard weather conditions like restricted rainfall. (Adekunle et al., 2012). It is the major source of energy, protein and still part of the major diet in most African countries because it has many nutritious, health benefits and medical functions, and its uses in food industry sector. (Amadou et al., 2011). Millets are classified with sorghum, maize, and Coix (Job's tears) in the grass sub-family Panicoideae (Yang et al., 2012). Millet is gluten-free, thus a premium option for people inmate from celiac diseases regularly irritated by the gluten content of wheat and other more common cereal grains. It is also beneficial for people who are suffering from atherosclerosis and diabetic heart disease (Gélinas et al., 2008).

Composed Flour is types of flour from grains other than wheat, legumes, carrot and tubers can be a mixture of flours other than wheat flour. (Okpala and Okoli, 2011). Composite flours are recently manufactured not only to improve the desired functional properties of end product based on them but also to improve nutritional composition (Ubbor and Akobundu, 2009). Good nutritional value of cereals concerns with their proteins, carbohydrates and fiber contents and appreciable quantities of vitamins and minerals (Hill and Path, 1998).

Looking to supply a gluten-free product with improved acceptance and that promote a possible increase in the absorption of vitamins and minerals in individuals with celiac disease, gluten-free product (da Silva and Conti-Silva, 2018). Studies performed on teenagers and young 


\section{Chemical and functional properties of free-gluten biscuit making from corn, quinoa and millet flours}

adults have exposed that biscuits are a popular foodstuff consumed by a varied range of population due to their varied taste, long shelf life and comparatively low cost. Millet is gluten-free, therefore a best option for persons inmate from celiac diseases regularly irritated by the gluten contented of wheat and other more common cereal grains. It is also helpful for persons who are suffering from atherosclerosis and diabetic heart disease (Lubna and Vidhu, 2012).

In that sense, the aim of this research study was to evaluate the chemical and functional properties of gluten-free biscuit formulation and their relation to final product quality making from different ratios of corn, quinoa and millet flours.

\section{MATERIALS AND METHODS \\ Materials}

Corn (Zea mays) seeds were obtained from Cereals and Pulses Maize Department, Field Crops Research Institute- Agricultural Research Center, Egypt. It was cleaned manually to remove stones, grit, chaff and other impurities then milled.

\section{Quinoa (Chenopodium quinoa Willd,)} seeds were obtained from Egyptian Company for Oils and Natural Products, Egypt. It was washed with water at $60^{\circ} \mathrm{C}$ (with agitation) during one hour 1:10 (w/v). Seeds were dried at $60^{\circ} \mathrm{C}$ using a convective dryer according to Margarita et al. (2010) then milled.

Millet (Pearl millet) seeds were obtained from local market. It was cleaned manually then milled.

Guar gum and Ssl (Sodium stearoyl-2lactylate) obtained from Chemitec International Technology Center- $6^{\text {th }}$ of October City, Egypt. Other ingredients (fat, sugar, egg, baking powder, and salt) were purchased from local market.
Preparation of whole flour sample: For compositional and nutritional analysis, all the samples under study were milled using a Hammer mill laboratory type [DCFH-48Germany], to obtain flour through sieve $0.1 \mathrm{~mm}$.

\section{Methods:}

\section{Proximate analysis}

Moisture, protein, fat, crude fiber, starch and ash content of the investigated samples (corn, quinoa and millet) were carried out according to the AOAC (2007). Total carbohydrate contents were tested quantitatively according to Kostas et al, (2016). The absorbance was measured at a wavelength of $490 \mathrm{~nm}$ using UV-Vis Shimadzu Spectrophotometer (UV-1601 PC).

Saponin was determined following the described method in Mastebroek et al. (2000)

Minerals $(\mathrm{Fe}, \mathrm{Ca}, \mathrm{K}$, and $\mathrm{Mg}$ ) contents were measured using Atomic Absorption (GBC 932/933-England) according to procedure outlined by AOAC (2007).

Vitamins namely (A), (C), (E) and vitamin (B complex) content were determined according to $\mathrm{J}$. of Chromatography B 830:41-46 (2006), A 935:71-76 (2001), B 816:67-72 (2005) and B 816:67-72 (2005), respectively.

Amino acids of the investigated samples were carried out as described by the method of the Association of Official Analytical Chemists (AOAC, No.994.12, 2012) using Amino acid analyser biochrom 30 U.K.

\section{Physical properties}

Bulk density: Loose and tapped bulk densities were calculated by the equation given by Baysal et al (2003): 
Samah M. Ismael et al.

$\mathrm{P}_{\mathrm{b}} \mathrm{g} / \mathrm{ml}=\mathrm{M} /\left(\mathrm{V}^{*} \mathrm{or}_{\mathrm{r}}\right)$

Where: $\mathrm{M}=$ Amount of the sample poured into the cylinder

$\mathrm{V}^{*}=$ First scale reading

$\mathrm{V}_{1}=$ Volume measured after 20 tapings

Water holding capacity (WHC) was determined according to Jongaroontaprangsee et al. (2007). It was calculated as the amount of water retained by the sample (g/g DMB) as follows: WHC $(\mathrm{g} / \mathrm{g})=\{$ Residue fresh weight $(\mathrm{g})$ Residue dried weight (g) $\} /$ Residue fresh weight (g)

\begin{tabular}{|l|l|l|l|}
\hline Sample & Mixtures of flour sample & Sample & Mixtures of flour sample \\
\hline Control & $100 \%$ corn & 7 & $75 \%$ quinoa $+25 \%$ corn \\
1 & $25 \%$ millet $+25 \%$ quinoa $+50 \%$ corn & 8 & $50 \%$ millet $+25 \%$ quinoa $+25 \%$ corn \\
2 & $25 \%$ millet $+50 \%$ quinoa $+25 \%$ corn & 9 & $50 \%$ millet $+50 \%$ quinoa \\
3 & $25 \%$ millet $+75 \%$ quinoa & 10 & $50 \%$ millet $+50 \%$ corn \\
4 & $25 \%$ millet $+75 \%$ corn & 11 & $75 \%$ millet $+25 \%$ quinoa \\
5 & $25 \%$ quinoa $+75 \%$ corn & 12 & $75 \%$ millet $+25 \%$ corn \\
6 & $50 \%$ quinoa $+50 \%$ corn & 7 & $75 \%$ quinoa $+25 \%$ corn \\
\hline
\end{tabular}

The eggs were initially homogenized with a hand blender (Braun, Kronberg, Germany) for a few seconds. Then the sugar, shortening, and syrup were mixed for $20 \mathrm{~s}$ with eggs in a moulinx mixer (LM240France). Half of the flour and all other ingredients were mixed for $20 \mathrm{~s}$. The remaining flour was added and mixed for $140 \mathrm{~s}$ to give a total mixing time of $3 \mathrm{~min}$. Following a rest time of $20 \mathrm{~min}$ the dough was sheeted to a final thickness of $3 \mathrm{~mm}$ using a pastry break. Dough pieces with a diameter of $70 \mathrm{~mm}$ were cut and placed on a non-stick baking tray and baked for $8 \mathrm{~min}$ in a deck oven (More -Turkey) at $230^{\circ} \mathrm{C}$ top heat and $200^{\circ} \mathrm{C}$ bottom heat. After $40 \mathrm{~min}$ cooling at room temperature, the biscuits were placed in polyethylene bags (Tilman $e t$ al., 2003).

\section{Sensory evaluation of biscuits}

Sensory evaluation of the biscuit samples was performed by 10 panelists of the Home Economic Dept., Fac. of Specific
Wettability was preformed according to the method of Pearson (1976).

\section{Process of Biscuit samples}

The straight dough procedure of biscuit processing was done using the following ingredients: flour $100 \mathrm{~g}$, sugar $35 \mathrm{~g}$, fat $30 \mathrm{~g}$, egg $27.5 \mathrm{~g}$, syrup $5 \mathrm{~g}$, guar gum $2.5 \mathrm{~g}$, salt $0.5 \mathrm{~g}$, Ssl $0.5 \mathrm{~g}$ and baking powder $0.5 \mathrm{~g}$. Flour of (corn, millet and quinoa) was supplemented with tested samples at different percentage of $25,50,75 \%$ as follows:
Education, Ain Shams univ. according to (Tilman et al., 2003). Palatability tests were considered in terms of color (20), break\& shred (20), crumb color (20), surface character (20), mouth feel (20) and overall acceptability (100), (Padma and Prabhasankar, 2013)

\section{Statistical analysis}

Analysis of Variance and Duncan's multiple range tests at 5\% level of significance was used to compare mean values of the tested factors. The analysis was carried out using the PROC ANOVA procedure of Statistical Analysis System (SAS, 1996).

\section{RESULTS AND DISCUSSION Technical aspects}

Saponins are plant glycosides that impart a bitter taste and tend to foam in water solutions. Until recently, saponins have been considered to be highly toxic, nevertheless, those present in foodstuffs are 


\section{Chemical and functional properties of free-gluten biscuit making from corn, quinoa and millet flours}

non-toxic and it has been recommended that they may be even beneficial in human food (Vilche et al., 2003).

The results showed that quinoa seeds contain saponin with $(0.035 \%)$. After washing and soaking saponin content was reduced to $0.022 \%$. So, it is in the acceptable range according to Koziol (1992) who reported that, quinoa was categorized as "sweet" being saponin free on with $<0.11 \%$ saponin on a fresh weight basis or "bitter" with $>0.11 \%$ saponins.

Saponins were reported by ValenciaChamorro (2003) as the main antinutritional factor found in quinoa grain. Most of the saponins were found concentrated in the outer husk of the grain (perianth, pericarp, seed coat, and a cuticlelike layer) which facilitated their subtraction industrially by abrasive dehulling or traditionally by soaking and washing the grains with water. The amount of saponins present depends on the variety of quinoa. It is higher in bitter-flavor varieties than in sweet, or low-saponins, varieties. Quinoa contains saponins in the amount from $0.1 \%$ to $5 \%$

\section{Chemical composition of corn, quinoa and millet flours}

The obtained results of corn, quinoa and millet grain are shown in Table (1). Corn flour had the highest percentage of moisture $(6.86 \%)$ compared to quinoa $(5.41 \%)$ and millet $(4.87 \%)$. On the other hands, millet flour has the highest percentage of ash $(4.86 \%)$ followed by corn $(4.26 \%)$ and quinoa $(2.97 \%)$. The highest percentage of fat was found in corn $(9.72 \%)$ followed by millet $(7.90 \%)$ and quinoa (6.55\%). Comai et al. (2007) demonstrated that, quinoa lipids appear to be a high-quality edible vegetable oil, same in the fatty-acid composition to soybean oil. Tang et al. (2015) recently revealed that the fatty acid composition of quinoa is
9.9_12.3\% saturated fat with palmitic acid predominant. Mono-unsaturated fat is $25.0 \_28.7 \%$ total fat and mainly oleic acid. Polyunsaturated fat is $56.20 \_58.3 \%$ total fat and is predominantly two essential fatty acids, linoleic acid (18:2n-6, an omega-6 fatty acid) and $\alpha$-linolenic acid (an omega-3 fatty acid). The unsaturated fatty acids are well protected from oxidation by a high level of naturally occurring vitamin $E$ present in the forms of tocopherols and tocotrienols. The omega-6/omega- 3 ratio is approximately $6 / 1$, which is more favorable than other plant oils regarding potential health benefits.

Quinoa and millet are worthy of consideration as important grain sources of protein being 15.10 and $12.50 \%$ in dry matter, respectively while corn is $(9.20 \%)$. Matiacevich et al. (2006) reported that, quinoa seeds have a high nutritional value in comparison to most cereals. The protein content of quinoa seeds showed from $8 \%$ to $22 \%$, which is higher on average than that in common cereals such as corn. In quinoa, maximum of the protein is positioned in the embryo. Albumins and globulins are the major protein fraction $(44-77 \%$ of total protein), which is greater than that of prolamins (0.5-7.0\%). Quinoa is considered to be a gluten-free grain for the reason that it content very little or no prolamin. Quinoa provides a nutritional, economical, easy-toprepare, flavorful food source which is of particular relevance for people with gluten intolerance, such as those with celiac disease (Valencia-Chamorro, 2003).

Millets are unique among the cereals because of their richness in protein especially significant amounts of essential amino acids, energy value, fat and minerals (Devi et al., 2011).

Also, results indicated that, millet and quinoa had high percentage of crude fiber $(4.28 \%)$ and $(3.94 \%)$, respectively as compared to corn $(2.76 \%)$. These data were 


\section{Samah M. Ismael et al.}

in agreement with Lamothe et al. (2015), who reported that quinoa contains $10 \%$ total dietary fiber. Fiber is the carbohydrate fraction which is resistant to enzymatic digestion and absorption in the small intestine, and which usually undergoes full or partial fermentation in the large intestine. Dietary fiber is considered essential for optimal digestive health, and it also adds functional benefits (Brownawell et al., 2012).

Results also indicated that no significant differences ( $p>0.05)$ among the corn, quinoa and millet samples in carbohydrates $(69.94,69.95$ and $69.84 \%$ ) respectively. Starch is an important part in carbohydrate, results showed that corn was $(41.29 \%)$, quinoa (46.97\%) and millet was (43.85\%). Valencia-Chamorro, (2003) reported that the main component in quinoa contains of carbohydrates, and varies from $67 \%$ to $74 \%$ of the dry matter. Starch makes about $52-60 \%$. The starch composite is located in the perisperm of the seeds; starch can be present as simple units or as spherical aggregates. Other, such as monosaccharides (2\%) and disaccharides $(2.3 \%)$, crude fiber $(2.5-3.9 \%)$, and pentosans (2.9-3.6\%). While carbohydrates are found in small amounts Devi et al. (2011) mention that millets show relatively higher than other cereals carbohydrate (72\%) comprises of starch as the main constituent and the nonstarchy polysaccharides which amounts to $15-20 \%$ of the seed matter as an unavailable carbohydrate dietary fiber content and complements which are the health benefits of the millet.

Table (1): Major chemical constituents (g\100g dry matter) of Corn, Quinoa and Millet.

\begin{tabular}{|l|l|l|l|}
\hline \multirow{2}{*}{ Constituents (\%) } & \multicolumn{3}{|c|}{ Mean \pm SDM of Samples } \\
\cline { 2 - 4 } & \multicolumn{1}{|c|}{ Corn } & \multicolumn{1}{c|}{ Quinoa } & \multicolumn{1}{c|}{ Millet } \\
\hline Moisture & $6.86 \pm 1.13^{\mathbf{a}}$ & $5.41 \pm 0.50^{\mathbf{a b}}$ & $4.87 \pm 0.61^{\mathbf{b}}$ \\
Ash & $4.26 \pm 0.13^{\mathbf{b}}$ & $2.97 \pm 0.03^{\mathbf{c}}$ & $4.86 \pm 0.00^{\mathbf{a}}$ \\
Protein & $9.20 \pm 1.10^{\mathbf{c}}$ & $15.10 \pm 1.40^{\mathbf{a}}$ & $12.50 \pm 2.90^{\mathbf{b}}$ \\
Fat & $9.72 \pm 0.13^{\mathbf{a}}$ & $6.55 \pm 0.20^{\mathbf{b}}$ & $7.9 \pm 0.20^{\mathbf{a b}}$ \\
Carbohydrates & $69.94 \pm 1.84^{\mathbf{a}}$ & $69.95 \pm 2.22^{\mathbf{a}}$ & $69.84 \pm 3.80^{\mathbf{a}}$ \\
Starch & $41.29 \pm 0.70^{\mathbf{b}}$ & $46.97 \pm 0.52^{\mathbf{a}}$ & $43.85 \pm 0.90^{\mathbf{b}}$ \\
Crude Fiber & $2.76 \pm 2.30^{\mathbf{b}}$ & $3.94 \pm 2.60^{\mathbf{a}}$ & $4.28 \pm 4.70^{\mathbf{a}}$ \\
\hline
\end{tabular}

Data are presented as means $\pm \operatorname{SDM}(n=3)$.

Means within a row with different letters are significantly different at $\mathrm{P} \leq 0.05$.

\section{Amino acids}

The 17 amino acids and their compositions identified of corn, quinoa and millet showed in Table (2). The highest amount of essential amino acids was Leucine which had a value of $9.89 \%$ dry matter in corn followed by millet $(9.76 \%)$ then quinoa $8.42 \%$. While the lowest one was Methionine which represent 2.85, 2.24 and $2.17 \%$ in quinoa, millet and corn respectively. Quinoa recorded the highest value of Lysine $(5.30 \%)$ comparable to corn and millet. Millet generally contains significant amounts of essential amino acids particularly the sulphur containing amino acids methionnine and cycsteine (2.87 and 3.60), respectively comparing with quinoa and corn. These results agree with Villa et al. (2014) who reported that seeds of quinoa content high protein average $12-18 \%$. Moreover, this protein is of an exceptionally high quality and is particularly rich in balanced composition of essential amino acids, such as sulfur amino acids, lysine and aromatic amino acids, higher than those recommended by FAO/WHO (2011) and 


\section{Chemical and functional properties of free-gluten biscuit making from corn, quinoa and millet flours}

which are deficient in most grain crops but necessary for proper nutrition in humans. This fact results in protein content comparable to casein that of whole dry milk (Villa et al., 2014) and this is in the line with results that showed millet and quinoa had the superior percentage of protein $(12.50$ and $15.10 \%)$ respectively while corn had $(9.20 \%)$. In general, cereal proteins including millets are limited in lysine and tryptophan content and vary with cultivar (Devi et al., 2011).

Out of the 17amino acids observed, 7 were classified as essential amino acids, and 2 were semi-essential (histidine and Arginine) is essential for children. Quinoa recorded the highest values of histidine and Arginine 3.38 and $9.34 \%$ respectively.
While, millet recorded the highest values of non-essential amino acids such as Alanine, Asprtic, 1/2Cysteine and Glutamic acids (8, $8.08,3.60$ and $19.44 \%$ ) respectively. Also in total non-essential amino acids millet was the highest value $54.8 \%$ followed by corn was $52.85 \%$ then quinoa $(50.57 \%)$. While, quinoa recorded the highest value in total essential and semi essential amino acids 32.93 and $12.72 \%$ respectively.

Essential amino acids must be consumed each day to replace the amino acids lost during normal metabolism, and to rebuild and repair the body (FAO, 2013). Vega-Galvez et al. (2010) reported that quinoa protein can supply over $180 \%$ of the daily recommended intake of essential amino acids for adult nutrition.

Table (2). Essential, non essential and semi essential amino acids (\%) of corn, quinoa and Millet.

\begin{tabular}{|c|c|c|c|}
\hline Amino acids (A.A) \% & Corn & Quinoa & Millet \\
\hline \multicolumn{4}{|c|}{ Essential Amino Acid (EAA) } \\
\hline Isoleucine (ILE) & 3.15 & 3.77 & 4.16 \\
\hline Leucine (LEU) & 9.89 & 8.42 & 9.76 \\
\hline Lysine (LYS) & 2.63 & 5.30 & 2.80 \\
\hline Phenylalanine (PHE) & 4.24 & 4.57 & 4.92 \\
\hline Threonine (THR) & 3.37 & 3.38 & 3.12 \\
\hline Valine (VAL) & 4.57 & 4.64 & 5.76 \\
\hline Methionine (MET) & 2.17 & 2.85 & 2.24 \\
\hline Total EAA & 30.02 & 32.93 & 32.76 \\
\hline \multicolumn{4}{|c|}{ Non-essential amino acids (NEAA) } \\
\hline Alanine (ALA) & 6.85 & 7.17 & 8.00 \\
\hline Asprtic (ASP) & 6.87 & 8.08 & 8.08 \\
\hline 1/2Cysteine (CYS) & 2.39 & 2.12 & 3.60 \\
\hline Glutamic (GLU) & 16.96 & 14.37 & 19.44 \\
\hline Glycine (GLY) & 3.48 & 5.17 & 3.04 \\
\hline Proline (PRO) & 8.37 & 6.44 & 6.00 \\
\hline Serine (SER) & 4.13 & 3.91 & 3.12 \\
\hline Tyrosine (TYR) & 3.80 & 3.31 & 3.52 \\
\hline Total NEAA & 52.85 & 50.57 & 54.80 \\
\hline \multicolumn{4}{|c|}{ Semi essential amino acids (SEAA) } \\
\hline Histidine (HIS) & 2.93 & 3.38 & 2.56 \\
\hline Arginine (ARG) & 4.13 & 9.34 & 4.64 \\
\hline Total SEAA & 7.06 & 12.72 & 7.20 \\
\hline Total AA & 89.93 & 96.22 & 94.76 \\
\hline
\end{tabular}


Samah M. Ismael et al.

\section{Minerals (Macro and micro elements)}

The results presented in Table (3) summarize the mineral composition of corn, quinoa and millet. Potassium $(\mathrm{K})$ had the highest value of the three samples followed by magnesium $(\mathrm{Mg})$ and calcium $(\mathrm{Ca})$ had the least value of samples among the macroelements.

Quinoa recorded the highest results of minerals, iron (4.47), calcium (82.78), magnesium (169.55) and potassium $(1508.64 \mathrm{mg} / 100 \mathrm{~g})$. This data agrees with Valencia-Chamorro (2003) who reported that Quinoa is a good source of minerals. It contains more iron, calcium, zinc and magnesium, than common cereals. USDA (2015) reported that, many minerals in quinoa are present in greater quantities than other grains, including phosphorus, magnesium, potassium, calcium, iron, zinc, and copper. The process of saponin removal decreases vitamin and mineral contents to an extent.

Millet takes the second level of minerals with 3.99, 72.59 and 157.69 $\mathrm{mg} / 100 \mathrm{~g}$ of iron, calcium and magnesium respectively. This result is close to Vijayakumari et al. (2003) who mentioned that millet is a riche source of iron and calcium. Calcium shortage leading to bone and teeth disorder, iron deficiency leading to anemia can be overwhelmed by presenting finger millet in our daily diet. Singh and Srivastava (2006) reported that, the iron content of 16 millet varieties ranged from3.61 $\mathrm{mg} / 100 \mathrm{~g}$ to $5.42 \mathrm{mg} \%$ with a mean value of $4.40 \mathrm{mg} / 100 \mathrm{~g}$ and this data agree with the result in Table (3) where millet contain $3.99 \mathrm{mg} / 100 \mathrm{~g}$.

Table (3). Mineral composition (mg/100g dry wt) of corn, quinoa and Millet.

\begin{tabular}{|l|c|c|c|}
\hline Minerals (mg/100g) & Corn & Quinoa & Millet \\
\hline Macro- elements & & & $72.59 \pm \pm 0.1^{\mathrm{b}}$ \\
Calcium (Ca) & $55.03 \pm 0.1^{\mathrm{c}}$ & $82.78 \pm \pm 0.4^{\mathrm{a}}$ & $157.69 \pm \pm 0.2^{\mathrm{ab}}$ \\
Magnesium (Mg) & $157.11 \pm \pm 0.1^{\mathrm{b}}$ & $169.55 \pm \pm 0.3^{\mathrm{a}}$ & $1202.18 \pm \pm 0.2^{\mathrm{c}}$ \\
Potassium (K) & $1284.62 \pm \pm 0.3^{\mathrm{b}}$ & $1508.64 \pm \pm 0.1^{\mathrm{a}}$ & \\
\hline Micro-elements & & & $3.99 \pm \pm 0.4^{\mathrm{b}}$ \\
Iron (Fe) & $2.99 \pm \pm 0.2^{\mathrm{c}}$ & $4.47 \pm \pm 0.2^{\mathrm{a}}$ & \\
\hline
\end{tabular}

While the results indicated that corn is less than quinoa in potassium $1284.62 \mathrm{mg} / 100 \mathrm{~g}$ and iron $2.99 \mathrm{mg} / 100 \mathrm{~g}$ as seen in Fig (1). All these minerals are necessary for physiological development and general well being of human being and animals. The deficiency of one or more of these mineral elements may constitute nutritional disorder in human (Abiose and Ikujenlola, 2014). 


\section{Chemical and functional properties of free-gluten biscuit making from corn,} quinoa and millet flours

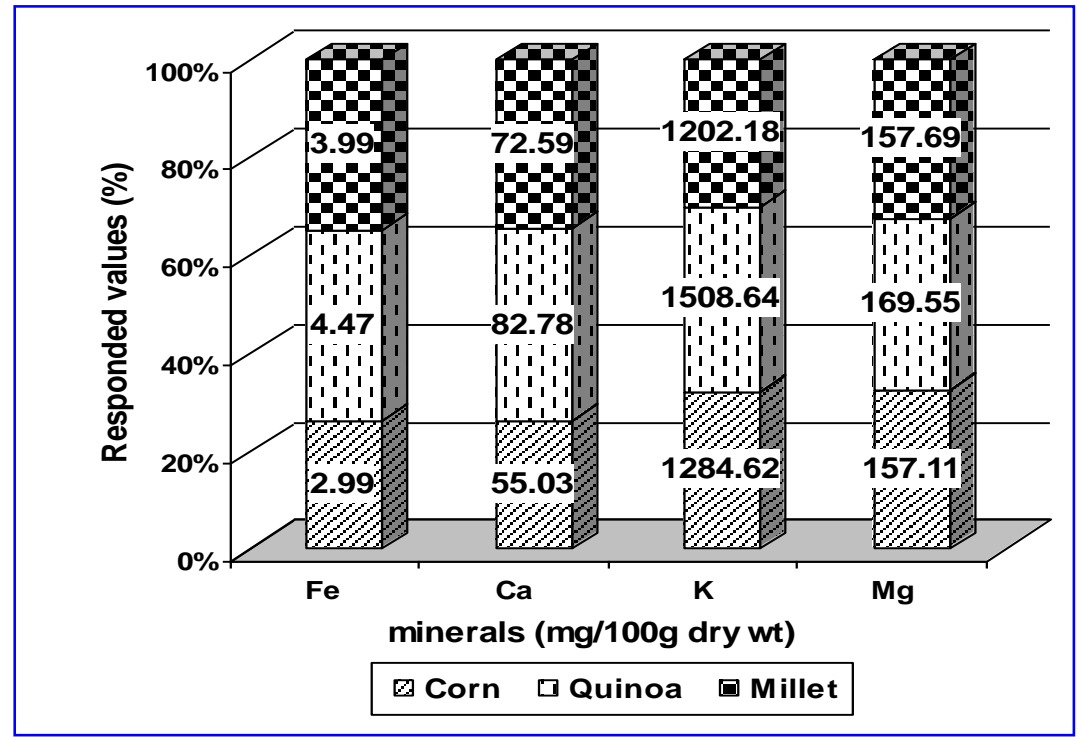

Fig. (1). Macro and micro minerals (mg/100g) of quinoa, millet and corn seeds.

\section{Vitamins}

Table (4) and Figure (2) show that quinoa seeds have more vitamin $C$, Nicotinic and Pyridoxin (67.34, 224.27 and $97.33 \mathrm{ppm}$ respectively) followed by corn then millet $(8.01,103.86$ and $38.97 \mathrm{ppm})$ and $(7.64,66.17$ and 35.42ppm) respectively. These results agree with USDA, (2015) mentioned that quinoa seeds are a rich source of vitamins, counting vitamin A precursor $\beta$-carotene, thiamin/vitamin B1, riboflavin/vitamin B2, niacin/vitamin B-3, ascorbic acid/vitamin C, folic acid/vitamin B9 and vitamin E B6, and pantothenic acid. Also, Fitzpatrick et al. (2012) mentioned that quinoa seeds are a good and rich source of vitamins, which are required in the human diet to act as enzymatic cofactors in metabolism, regulate cell growth and development, protect against oxidative damage, improve vision, and play beneficial roles in various other physiological processes.

Table (4). Vitamins analyses (ppm) of corn, quinoa and millet seeds.

\begin{tabular}{l|c|c|c|}
\hline Vitamins & Corn & Quinoa & Millet \\
\hline Vitamin A $(\mu \mathrm{g} / 100 \mathrm{~g})$ & $391.79^{\mathbf{a}}$ & $294.42^{\mathbf{b}}$ & $115.68^{\mathbf{c}}$ \\
Vitamin E ( $\mu \mathrm{g} / 100 \mathrm{~g})$ & $40.48^{\mathbf{a}}$ & $11.71^{\mathbf{b}}$ & $8.33^{\mathbf{c}}$ \\
Vitamin C (ppm) & $8.01^{\mathbf{b}}$ & $67.34^{\mathbf{a}}$ & $7.64^{\mathbf{c}}$ \\
\hline \multicolumn{3}{|l}{} \\
\hline Vitamin B complex (ppm) & $103.86^{\mathbf{b}}$ & $224.27^{\mathbf{a}}$ & $66.17^{\mathbf{c}}$ \\
Nicotinic acid (B3) & $3.07^{\mathbf{a}}$ & $2.788^{\mathbf{b}}$ & $2.65^{\mathbf{b}}$ \\
Thiamin (B1) & $38.97^{\mathbf{b}}$ & $97.33^{\mathbf{a}}$ & $35.42^{\mathbf{c}}$ \\
Pyridoxin (B6) & $15.23^{\mathbf{a}}$ & $7.60^{\mathbf{b}}$ & $7.88^{\mathbf{b}}$ \\
Ribiflac acid & $28.06^{\mathbf{b}}$ & $13.94^{\mathbf{c}}$ & $38.92^{\mathbf{a}}$ \\
B12 & $29.07^{\mathbf{c}}$ & $71.95^{\mathbf{b}}$ & $116.01^{\mathbf{a}}$ \\
\hline
\end{tabular}

*Values are means of triplicate readings.

Means within a raw with different letters are significantly different at $\mathrm{P} \leq 0.05$. 
Samah M. Ismael et al.

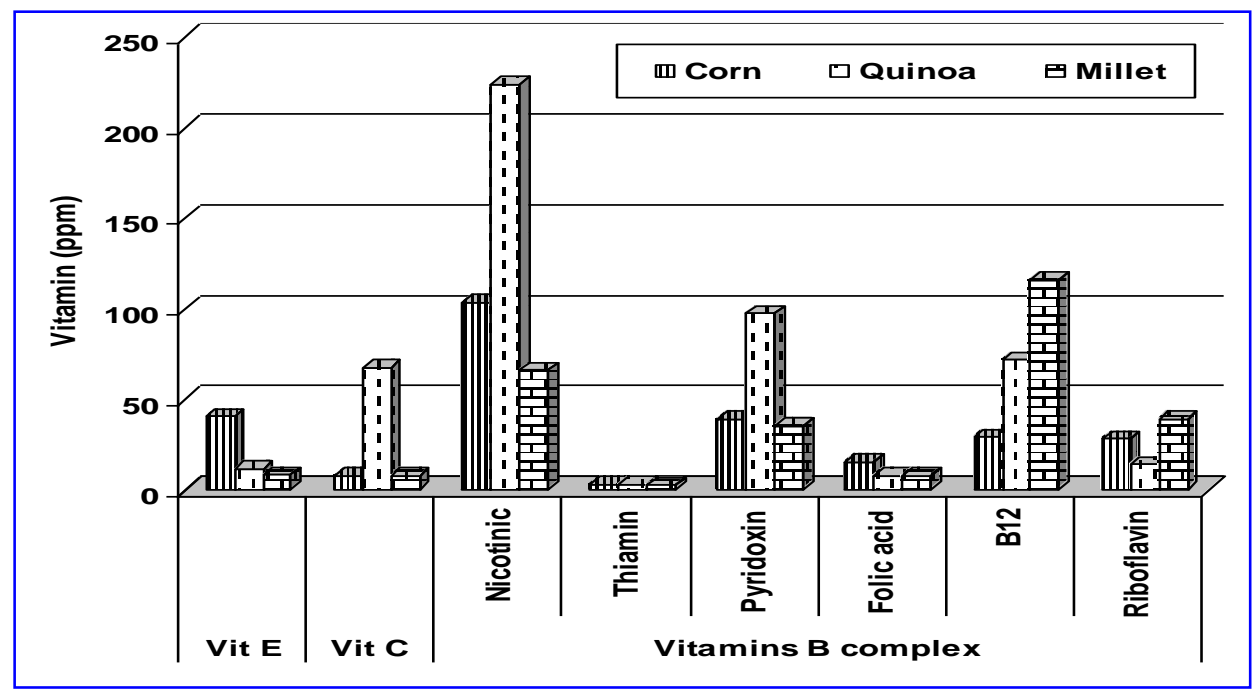

Fig. (2). Comparison between corn, quinoa and millet on vitamins E, C and B complex.

The vitamins soluble in fat (Vit. A and Vit.E) are found to be the highest ratio in corn followed by quinoa then millet (391.7885 and $40.48049 \mu \mathrm{g} / 100 \mathrm{~g}$ ), $(294.4231$ and $11.71329 \mu \mathrm{g} / 100 \mathrm{~g})$ and (115.6823 and $8.333006 \mu \mathrm{g} / 100 \mathrm{~g}$ ), respectively.

\section{Water holding capacity (WHC)}

Functional properties are controlled by the composition and structure of proteins and the interactions of proteins with one another and with other substances. Waterholding capacity (WHC) is an important protein-water interaction that occurs in various food systems. WHC represents the ability of a protein matrix to absorb and retain bound, hydrodynamic, capillary, and physically entrapped water against gravity (Damodaran and Paraf, 1997). The obtained results show that water holding capacity WHC is increased in $(25 \%$ quinoa $+75 \%$ corn) was $0.87 \mathrm{~g} / \mathrm{gDMB}$ followed by $(50 \%$ millet $+25 \%$ quinoa $+25 \%$ corn ) $0.72 \mathrm{~g} / \mathrm{g}$ as seen in Fig (3). While the samples (75\% millet $+25 \%$ quinoa) and $(25 \%$ millet+ $25 \%$ quinoa $+50 \%$ corn) were recorded the lest values $0.66 \mathrm{~g} / \mathrm{g}$ DMB comparing with the control $100 \%$ corn $0.71 \mathrm{~g} / \mathrm{gDMB}$ as seen in Table (5). On the other hand, these results suggested that dietary fibers from all samples containing quinoa with corn in different ratios $(70 \mathrm{~g} / \mathrm{g})$ could aid gel formation and enhance texture stability of food products such as bread and other baked products. In contrast, low WHC of samples containing quinoa with millet ranged between $66-69 \mathrm{~g} / \mathrm{gDMB}$ may be due to the damage of fiber matrix and the collapse of the pore during grinding. Jideani (2011) reported that water holding capacity of highly protein content is very significant as it affects the texture, juiciness, and taste of food formulations and in particular the shelflife of bakery products. Water plays an important role in the main changes that occur thru baking, which include starch gelatinization, protein denaturation, yeastand enzyme-inactivation, flavor and color formation (Pomeranz, 1985). 


\section{Chemical and functional properties of free-gluten biscuit making from corn, quinoa and millet flours}

Table (5). Loss bulk density, tapped bulk density, WHC and Wettability of tasted flower samples.

\begin{tabular}{|c|c|c|c|c|c|}
\hline \multirow{2}{*}{ Blended samples } & \multicolumn{3}{|c|}{ Bulk density $\left(\mathrm{g} / \mathrm{cm}^{3}\right)$} & \multirow{2}{*}{$\begin{array}{c}\text { WHC } \\
\text { (g/g DMB) }\end{array}$} & \multirow{2}{*}{ Wettability (S) } \\
\hline & Loss & Tapped & Difference & & \\
\hline $25 \% \mathrm{M}+75 \% \mathrm{Q}$ & $0.406 \pm 0.01^{\mathrm{c}}$ & $0.631 \pm 0.02^{\mathrm{e}}$ & 0.225 & $0.69 \pm 0.02^{\mathrm{e}}$ & $2.88 \pm 0.47^{\mathrm{e}}$ \\
\hline $25 \% \mathrm{M}+75 \% \mathrm{C}$ & $0.402 \pm 0.004^{c}$ & $0.672 \pm 0.01^{\mathrm{de}}$ & 0.270 & $0.69 \pm 0.20^{\mathrm{e}}$ & $3.81 \pm 0.39^{\mathrm{abc}}$ \\
\hline $50 \% \mathrm{M}+50 \% \mathrm{Q}$ & $0.409 \pm 0.01^{\mathrm{c}}$ & $0.737 \pm 0.05^{\mathrm{bcd}}$ & 0.328 & $0.68 \pm 0.03^{\mathrm{f}}$ & $3.50 \pm 0.06^{\text {bcde }}$ \\
\hline $50 \% \mathrm{M}+50 \% \mathrm{C}$ & $0.400 \pm 0.00^{\mathrm{c}}$ & $0.715 \pm 0.02^{\mathrm{bcd}}$ & 0.315 & $0.67 \pm 0.02^{\mathrm{g}}$ & $3.39 \pm 0.08^{\text {bcde }}$ \\
\hline $75 \% \mathrm{M}+25 \% \mathrm{Q}$ & $0.407 \pm 0.01^{\mathrm{c}}$ & $0.696 \pm 0.03^{\text {bcde }}$ & 0.289 & $0.66 \pm 0.02^{h}$ & $3.23 \pm 0.06^{\mathrm{cde}}$ \\
\hline $75 \% \mathrm{M}+25 \% \mathrm{C}$ & $0.426 \pm 0.03^{\mathrm{bc}}$ & $0.770 \pm 0.10^{\mathrm{ab}}$ & 0.344 & $0.67 \pm 0.03^{\mathrm{g}}$ & $3.06 \pm 0.61 \mathrm{de}$ \\
\hline $25 \% Q+75 \% C$ & $0.409 \pm 0.01^{\mathrm{c}}$ & $0.744 \pm 0.03^{\mathrm{bcd}}$ & 0.335 & $0.87 \pm 0.03^{\mathrm{a}}$ & $3.42 \pm 0.17^{\text {bcde }}$ \\
\hline $50 \% \mathrm{Q}+50 \% \mathrm{C}$ & $0.428 \pm 0.01^{b}$ & $0.669 \pm 0.01^{\mathrm{de}}$ & 0.241 & $0.70 \pm 0.02^{\mathrm{d}}$ & $3.22 \pm 0.05^{\mathrm{cde}}$ \\
\hline $75 \% Q+25 \% \mathrm{C}$ & $0.423 \pm 0.01^{\mathrm{bc}}$ & $0.632 \pm 0.03^{\mathrm{e}}$ & 0.209 & $0.70 \pm 0.03^{\mathrm{d}}$ & $3.92 \pm 0.17^{\mathrm{ab}}$ \\
\hline $25 \% \mathrm{M}+25 \% \mathrm{Q}+50 \% \mathrm{C}$ & $0.416 \pm 0.02^{\mathrm{c}}$ & $0.745 \pm 0.02^{\mathrm{bcd}}$ & 0.329 & $0.66 \pm 0.01^{\mathrm{h}}$ & $3.92 \pm 0.32^{\mathrm{ab}}$ \\
\hline $25 \% \mathrm{M}+50 \% \mathrm{Q}+25 \% \mathrm{C}$ & $0.483 \pm 0.01^{\mathrm{a}}$ & $0.763 \pm 0.03^{\mathrm{bc}}$ & 0.280 & $0.69 \pm 0.014^{\mathrm{e}}$ & $3.72 \pm 0.24^{\mathrm{bcd}}$ \\
\hline $50 \% \mathrm{M}+25 \% \mathrm{Q}+25 \% \mathrm{C}$ & $0.400 \pm 0.00^{\mathrm{c}}$ & $0.685 \pm 0.03^{\text {cde }}$ & 0.285 & $0.72 \pm 0.02^{b}$ & $4.46 \pm 0.08^{\mathrm{a}}$ \\
\hline $100 \% \mathrm{C}$ & $0.455 \pm 0.03^{\mathrm{ab}}$ & $0.830 \pm 0.04^{\mathrm{a}}$ & 0.375 & $0.71 \pm 0.02^{\mathrm{c}}$ & $4.01 \pm 0.48^{\mathrm{ab}}$ \\
\hline
\end{tabular}

$*$ Values are means of triplicate readings. $\mathrm{DMB}=$ Dry matter basis $\mathrm{Q}=$ quinoa $\mathrm{M}=$ millet $\mathrm{C}=$ corn Means within a column with different letters are significantly different at $\mathrm{P} \leq 0.05$.

To establish the techno-functional properties of quinoa flours, water-holding capacity (WHC) was assessed. WHC allow assessing the flour aptitude to retain water under a centrifugal gravity force, considering physically entrapped, capillary, bound and hydrodynamic water. Ogungbenle et al. (2009) who mentioned that quinoa flours were capable of retaining $147 \%$ of its weight in water.

WHC is important indicator to evaluate the functions of dietary fiber because it is always closely related to the cholesterol-lowering ability of dietary fiber (Li et al., 2013). WHC increased gradually with adsorption time increasing in the first 2 $\mathrm{h}$, and then WHC kept stable.

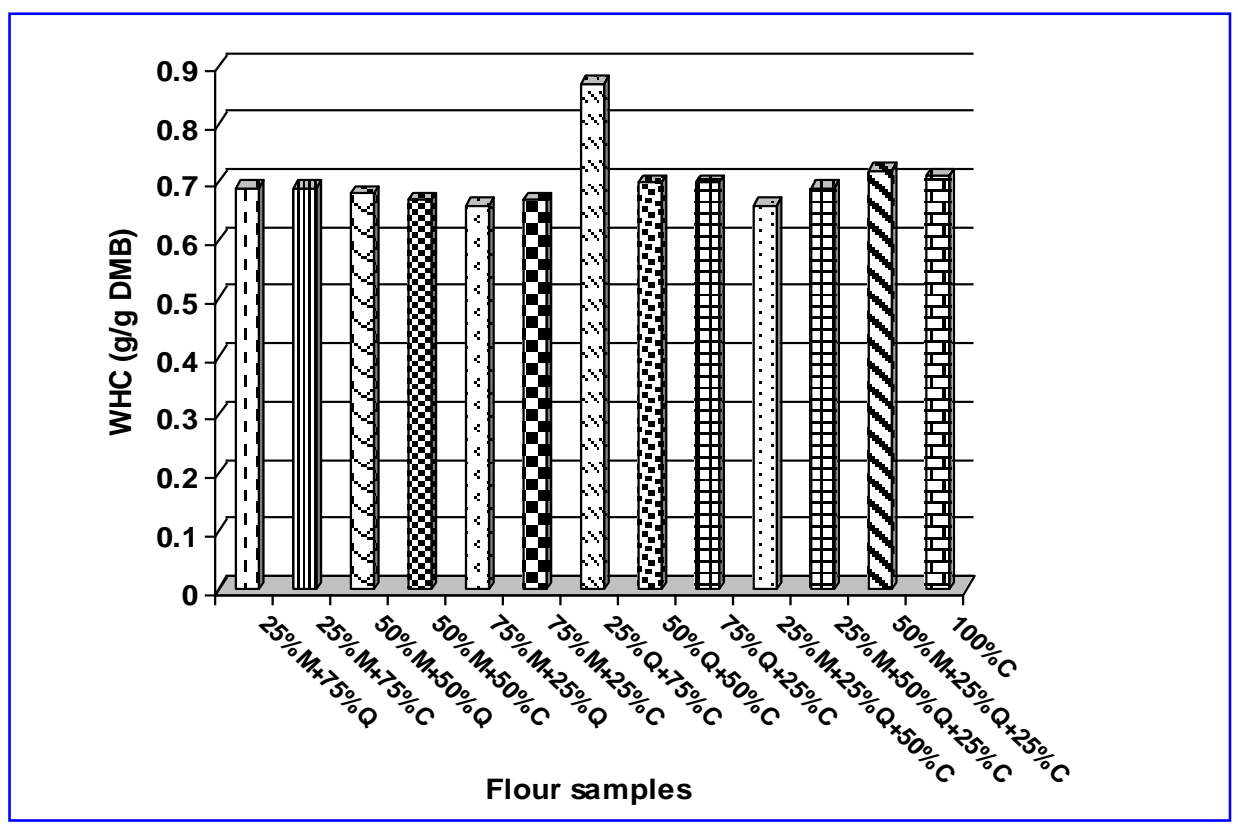

Fig. (3). Comparison between blended flour samples of corn, quinoa and millet on WHC. 
Samah M. Ismael et al.

\section{Bulk density}

The loose and tapped bulk density of the investigated samples is given in Table (5). Bulk density of the prepared powder was completely differed within the kind of the samples. The highest loose porosity values were found for 25\%Millet+50\%Quinoa+25\%Corn samples were $0.483 \mathrm{~g} / \mathrm{cm}^{3}$. While the corn sample was the highest value in the tapped density of $0.830 \mathrm{~g} / \mathrm{cm}^{3}$ followed by $75 \%$ Millet + $25 \%$ Corn $\left(0.770 \mathrm{~g} / \mathrm{cm}^{3}\right)$ and the difference was 0.375 and $0.344 \mathrm{~g} / \mathrm{cm}^{3}$ respectively. This trend may be related to the particle size of the granules which being of lowest diameter or indicated that degree of fineness was absolutely inherent within the fat content which acting as adhering substances and preventing the molecules to be oriented in a homogenous matter. Other possible explanation is that, the presences of higher level of fat (as see in Table 1) usually minimize the bulk density. These results are close to the opinion of Peleg and Bagley (1983) who stated that, it is still evident by that the properties of any low-density powders cannot be explained by gemotric consideration only, but also to their physical as well as their chemical properties. The lowest differences between loss and tapped bulk density were found in $75 \% \mathrm{Q}+25 \% \mathrm{C}$ $\left(0.209 \mathrm{~g} / \mathrm{cm}^{3}\right)$ followed by $25 \% \mathrm{M}+75 \% \mathrm{Q}$ $\left(0.225 \mathrm{~g} / \mathrm{cm}^{3}\right)$. Krokida and Maroulis (1999) stated that the significant different bulk density values of a product can be instigated by difference in particle size or dry matter content. It is of interest to mention that most food powders are known to be cohesive, which means that their particle attraction forces are significantly higher in relation to the particles own weight, (Dobbs et al., 1982). Another notable exception to this trend is the case of fine powders that very cohesive even in their dry form. (Baysal et al., 2003).

\section{Wettability}

Wettability actions of the different samples were also measured as seen in the Table (5). The following results were obtained, the highest wettability was $(50 \%$ Millet+25\% Quinoa+25\%Corn) $4.46 \mathrm{~S}$ and on the contrary $25 \%$ Millet $+75 \%$ Quinoa recorded the lowest wettability $2.88 \mathrm{~S}$. Typically, a increase wettability time for sample was associated with an increase in wettability in all samples from 3: $4 \mathrm{~S}$ in all tested sample.

Wettability is one of the properties that may influence the general reconstitution and/or mixing characteristics. Many of conventional dry sample powders need long time to wet reflecting little wettability, because of low specific surface area and particle's texture/microstructure, and chemical composition Liapis and Bruttini (1995). Wettability is a measure of the ability of powder to absorb water. Thus, the more the wetting time, the lower the wettability Singh and Rai (1998). These results are mainly correlated with the structural configurations and the chemical constituents of the tested samples. Such pattern of results is in parallel with Liapis and Bruttini (1995) who also demonstrated that in some cases, complete structural rigidity may hamper or contradicted rehydration due to the absence of pathways for the entrance of water.

\section{Sensory characteristics of biscuits}

The Sensory evaluation of biscuits baked from suggested powder samples from corn + Millet + Quinoa at ratios 25, 50 and $75 \%$ are shown in Table (6). 


\section{Chemical and functional properties of free-gluten biscuit making from corn, quinoa and millet flours}

Table (6). Mean score values of the sensory attributes of biscuits mad from tested flour samples.

\begin{tabular}{|c|c|c|c|c|c|c|}
\hline \multirow[b]{2}{*}{ Treatments } & \multicolumn{5}{|c|}{ Mean of scoring tested parameters out of (20) } & \multirow{2}{*}{$\begin{array}{c}\text { Over all } \\
\text { acceptability } \\
(\mathbf{1 0 0})\end{array}$} \\
\hline & Color & $\begin{array}{c}\text { Break \& } \\
\text { shred }\end{array}$ & $\begin{array}{c}\text { Crumb } \\
\text { color }\end{array}$ & $\begin{array}{c}\text { Surface } \\
\text { character }\end{array}$ & Mouth feel & \\
\hline $25 \% \mathrm{M}+25 \% \mathrm{Q}+50 \% \mathrm{C}$ & $13.4 \pm 2.1^{\mathrm{bc}}$ & $12.7 \pm 2.6^{b c}$ & $12.0 \pm 2.2^{\mathrm{cd}}$ & $12.6 \pm 3.1^{b}$ & $11.3 \pm 1.5^{\mathrm{d}}$ & $58.3 \pm 11.5^{\mathrm{e}}$ \\
\hline $25 \% \mathrm{M}+50 \% \mathrm{Q}+25 \% \mathrm{C}$ & $12.4 \pm 2.0^{\mathrm{c}}$ & $13.1 \pm 2.3^{b c}$ & $11.4 \pm 1.7^{\mathrm{d}}$ & $13.1 \pm 2.8^{b}$ & $11.1 \pm 1.5^{\mathrm{d}}$ & $59.3 \pm 8.2^{d}$ \\
\hline $25 \% \mathrm{M}+75 \% \mathrm{Q}$ & $12.4 \pm 1.7^{\mathrm{c}}$ & $12.1 \pm 1.7^{\mathrm{c}}$ & $11.9 \pm 2.3^{\mathrm{cd}}$ & $12.3 \pm 2.1^{\mathrm{b}}$ & $12.9 \pm 1.3^{\mathrm{dc}}$ & $58.8 \pm 8.3^{\mathrm{e}}$ \\
\hline $25 \% \mathrm{M}+75 \% \mathrm{C}$ & $13.6 \pm 3.5^{\mathrm{bc}}$ & $13.5 \pm 3.0^{\mathrm{bc}}$ & $14.0 \pm 3.5^{b c}$ & $13.4 \pm 3.8^{b}$ & $13.2 \pm 2.9^{\mathrm{dc}}$ & $67.7 \pm 12.9^{b c}$ \\
\hline $25 \% \mathrm{Q}+75 \% \mathrm{C}$ & $15.0 \pm 2.1^{\mathrm{b}}$ & $14.9 \pm 2.1^{\mathrm{b}}$ & $15.5 \pm 1.9^{b}$ & $15.0 \pm 3.0^{\mathrm{b}}$ & $14.9 \pm 1.9^{b}$ & $74.3 \pm 9.6^{b}$ \\
\hline $50 \% \mathrm{Q}+50 \% \mathrm{C}$ & $14.4 \pm 3.6^{\mathrm{bc}}$ & $13.1 \pm 2.6^{b c}$ & $14.6 \pm 2.8^{\mathrm{b}}$ & $14.1 \pm 2.4^{b}$ & $13.2 \pm 3.1^{\mathrm{cd}}$ & $69.4 \pm 9.9^{b c}$ \\
\hline $75 \% \mathrm{Q}+25 \% \mathrm{C}$ & $14.2 \pm 2.7^{\mathrm{bc}}$ & $14.5 \pm 3.3^{\mathrm{ab}}$ & $13.5 \pm 2.1^{b c}$ & $15.1 \pm 2.2^{\mathrm{ab}}$ & $14.1 \pm 1.7^{\mathrm{bc}}$ & $71.4 \pm 8.6^{\mathrm{bc}}$ \\
\hline $50 \% \mathrm{M}+25 \% \mathrm{Q}+25 \% \mathrm{C}$ & $13.4 \pm 2.1^{b c}$ & $14.2 \pm 2.0^{\mathrm{ab}}$ & $14.6 \pm 0.9^{b}$ & $14.0 \pm 2.8^{b}$ & $12.4 \pm 1.8^{\mathrm{d}}$ & $68.6 \pm 6.6^{c}$ \\
\hline $50 \% \mathrm{M}+50 \% \mathrm{Q}$ & $13.7 \pm 2.0^{\mathrm{bc}}$ & $13.1 \pm 2.5^{b c}$ & $13.6 \pm 2.3^{c}$ & $12.3 \pm 1.6^{\mathrm{b}}$ & $12.7 \pm 2.2^{\mathrm{cd}}$ & $65.4 \pm 7.0^{\mathrm{bc}}$ \\
\hline $50 \% \mathrm{M}+50 \% \mathrm{C}$ & $14.6 \pm 2.9^{b c}$ & $14.4 \pm 2.1^{\mathrm{ab}}$ & $13.3 \pm 2.7^{b c}$ & $13.9 \pm 1.8^{b}$ & $13.7 \pm 1.5^{b c}$ & $69.9 \pm 8.2^{b c}$ \\
\hline $75 \% \mathrm{M}+25 \% \mathrm{Q}$ & $12.6 \pm 1.2^{b c}$ & $12.5 \pm 1.2^{b c}$ & $13.3 \pm 2.0^{b c}$ & $13.1 \pm 1.8^{b}$ & $13.0 \pm 2.1^{\mathrm{c}}$ & $64.5 \pm 4.7^{\mathrm{cd}}$ \\
\hline $75 \% \mathrm{M}+25 \% \mathrm{C}$ & $13.4 \pm 2.0^{\mathrm{bc}}$ & $14.1 \pm 2.4^{\mathrm{ab}}$ & $13.2 \pm 1.6^{b c}$ & $15.0 \pm 2.8^{\mathrm{ab}}$ & $13.9 \pm 2.4^{b c}$ & $69.6 \pm 6.1^{b c}$ \\
\hline $100 \% \mathrm{C}$ & $19.2 \pm 1.6^{\mathrm{a}}$ & $16.5 \pm 3.5^{\mathrm{a}}$ & $17.6 \pm 2.9^{\mathrm{a}}$ & $17.4 \pm 3.6^{\mathrm{a}}$ & $16.5 \pm 3.4^{\mathrm{a}}$ & $87.2 \pm 9.8^{\mathrm{a}}$ \\
\hline
\end{tabular}

*Values are means of triplicate readings. $\mathrm{Q}=$ quinoa $\mathrm{M}=$ millet $\mathrm{C}=$ corn

Means within a column with different letters are significantly different at $\mathrm{P} \leq 0.05$.

The obtained results indicated that, increasing the level of corn flour increased sensory scores of biscuits for color, Break and shred, crumb color, surface character, mouth feel and over all acceptability as seen in blended $25 \% \mathrm{Q}+75 \%$ corn followed by $75 \% \mathrm{Q}+25 \% \mathrm{C}$ over all acceptability was $74.3 \pm 9.6$ and $71.4 \pm 8.6$ respectively as seen in Figure (4). Whereas control biscuit (100\% corn) sample had the highest value in all parameters and over all acceptability was (87.2 \pm 9.8$)$ compared to other tested samples. While there were no significant differences in samples $(25 \%$ Millet $+25 \%$ Quinoa+50\% Corn) and (25\% Millet+50\%
Quinoa+25\% Corn) in surface character and mouth feel were and they recorded the lowest values, the overall capacity of them was $58.3 \pm 11.5$ and $59.3 \pm 8.2$ respectively. In conclusion, addition corn flour by each ratio to quinoa or millet record good values and satisfied acceptable about blended the three samples with each other. These results agree with Handa et al., (2012) who reported that, corn flour is related to cultural or social preferences and some of the products are more suitable for commercial trade because they require further processing or provide convenience and extended shelf life.

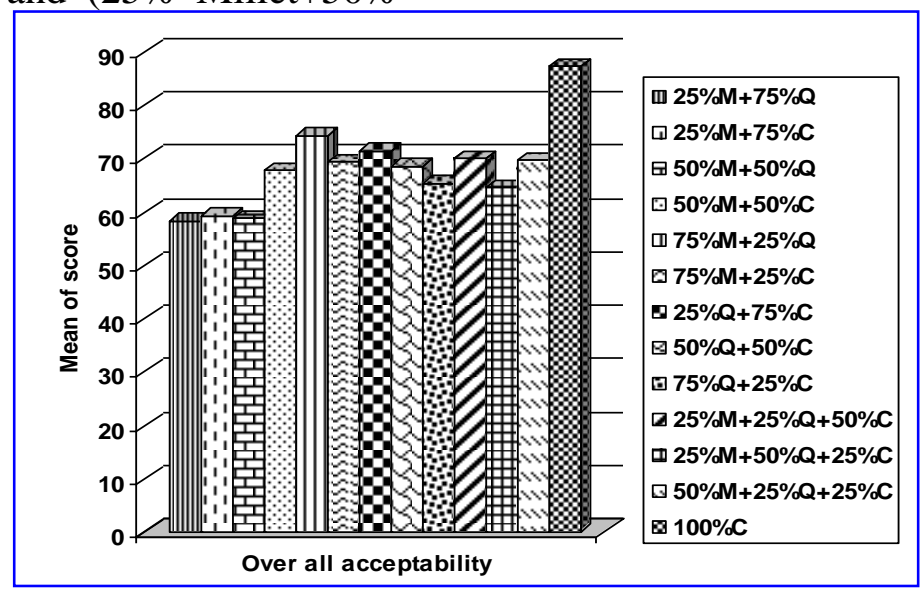

Fig. (4). Over all acceptability of biscuits made from blended flour samples of corn, quinoa and millet. 
Samah M. Ismael et al.

\section{REFERENCES}

A.O.A.C. (2007). Official Methods of Analysis of the Association of Official Analytical Chemists. $18^{\text {th }}$ Ed. Published by Association of Official Analytical Chemists, Gaithersburg, MD, USA.

A.O.A.C. (2012). Official Methods of Analysis (19thed.). Arlington, VA, USA: Association of Official Analytical Chemists.

Abiose, S.H. and Ikujenlola, A.V. (2014). Comparison of chemical composition, functional properties and amino acids composition of quality protein maize and common maize (Zea mays L). Afr. J. Food Sci. Technol, 5(3):81-89.

Adekunle A.A., Ellis-Jones J., Ajibefun I., Nyikal R.A., Bangali S., Fatunbi O., Angé A. (2012). Agricultural innovation in Sub-Saharan Africa : experiences from multiplestakeholder approaches. ISBN 9789988-8373-2-4.

Ajanovic, A. (2011). Biofuels versus food production: does biofuels production increase food prices? Energy, 36 (4): 2070-2076. At: https://doi.org/10.1016/j.energy.2010.05.019

Amadou, I.; Gbadamosi, O.S. and Guo-Wei, L. (2011). Millet-based traditional processed foods and beverages-A review. Cereal Food World, 56(3):115-121.

Baysal, T.; Icier, F.; Ersus, S., and Yildiz, H. (2003). Effects of microwave and infrared drying on the quality of carrot and garlic. Eur. Food Res. Technol., 218: 68-73.

Brownawell, A.M.; Caers, W.; Gibson, G.R.; Kendall, C.W.C. , Lewis, K.D. Ringel Y and Slavin JL. (2012). Prebiotics and the health benefits of fiber: current regulatory status, future research, and goals. J Nutr.; 142:962-974.

Comai, S.; Bertazzo, A.; Bailoni, L.; Zancato, M.; Costa, C.V.L. and Allegri G. (2007). The content of proteic and nonproteic (free and protein bound) tryptophan in quinoa and cereal flours. Food Chem., 100: 1350-1355.

da Silva, T.F. and Conti-Silva, A.C. (2018). Potentiality of gluten-free chocolate cookies with added inulin/oligofructose: Chemical, physical and sensory characterization. LWT - Food Sci. Technol., 90:172-179

Damodaran, S. and Paraf, A. (1997). Food proteins and their applications. Marcel Dekker, New York, 696.

Darvey, N.L.; Naeem, H., and Gustafson, J.P. (2000). Triticale: production and utilization. Chapter 9 in: Handbook of Cereal Science and Technology, 2nd ed. (eds. K. Kulp, J. Ponte). Marcel Dekker, New York, pp: 257274.

Devi, P.B.; Vijayabharathi, R.; Sathyabama, S.; Malleshi, N.G. and Priyadarisini, V.B. (2011). Health benefits of finger millet (Eleusine coracana L.) polyphenols and dietary fiber: a review. J. Food Sci. Technol., 51(6): 1021-1040. DOI: $10.1007 / \mathrm{s} 13197-$ 011-0584-9

Dobbs, A.J.; Peleg, M.; Mudgett, R.E. and Rufner, R. (1982). Some physical characteristics of active dry yeast. Powder Technol., 32-75.

FAO/WHO (2011). Quinoa: An ancient crop to contribute to world food security. Regional Office for Latin America and the Caribbean.

FAO (2013). Dietary protein quality evaluation in human nutrition. Report of an FAO Expert 


\section{Chemical and functional properties of free-gluten biscuit making from corn, quinoa and millet flours}

Consultation March 31-April 2, 2011. Food and Nutrition Paper 92.

Fischer, S.; Wilckens, R.; Jara, J.; Aranda, M.; Valdivia, W.; Bustamante, L.; Grafa, F. and Obala, I. (2017). Protein and antioxidant composition of quinoa (Chenopodium quinoa Willd) sprout from seeds submitted to water stress, salinity and light condition. Ind. Crops Prod., 107: $558-564$.

Fitzpatrick, D.; Scanlon, E.; Krüse, J.; Vos, B.; Evans-Hurson, R.; Fitzpatrick, E. and McSweeney, S. (2012). Blend uniformity analysis of pharmaceutical products by Broadband Acoustic Resonance Dissolution Spectroscopy (BARDS), Int. J. Pharm., 438(1-2): 134-139

Gawlik-Dziki, U.; Świeca, M.; Sułkowski, M.; Dziki, D.; Baraniak, B., and Czyz, J. (2013). Antioxidant and anticancer activities of Chenopodium quinoa leaves extracts - In vitro study. Food Chem. Toxicol., 57: 154-160.

Gélinas, P.; McKinnon, C. M.; Mena, M. C., and Méndez, E. (2008). Gluten contamination of cereal foods in Canada. Int. J. Food Sci. Technol., 43(7):1245-1252.

Gordillo-Bastidas, E.; Díaz-Rizzolo, D.A.; Roura, E.; Massanés, T. and Gomis, R., (2016). Quinoa (Chenopodium quinoa Willd), from nutritional value to potential health benefits: an integrative review. J. Nutr. Food Sci., 63 (3): 1-10.

Graf, B.L.; Rojas-Silva, P.; Rojo, L.E.; Delatorre-Herrera, J.; Baldeón, M.E. and Raskin, I. (2015). Innovations in health value and functional food development of quinoa (Chenopodium quinoa Willd). Comp. Rev. Food Sci. Food Saf., 14(4): 431-445.
Handa, C.; Goomer, S. and Siddhu, A. (2012). Physicochemical properties and sensory evaluation of fructooligosaccharide enriched cookies. J. Food Sci. Technol., 49(2): 192-199.

Hill, M.J. and Path, F.R. (1998). Cereals, dietary fiber and cancer. Nutr. Res., 18(4): 563-659.

Jideani, V.A. (2011). Functional properties of soybean food ingredients in food systems. In Ng PT-B editor; Soybean - Biochemistry, Chemistry and Physiology: InTech, 2011.

Jongaroontaprangsee, S.; Tritrong, W. and Chokanaporn, W., (2007). Effects of drying temperature and particle size on hydration properties of dietary fiber powder from lime and cabbage by-products. Int. J. Food Proper, 10: 887-897.

Kostas, T.E.; Wilkinson, J.S.; White, A.D. and Cook, J.D. (2016). Optimization of a total acid hydrolysis based protocol for the quantification of carbohydrate in macro algae. J. Algal Biomass Utin. 7(1):21-36.

Koziol M.J. (1992). Chemical composition and nutritional evaluation of quinoa (Chenopodium quinoa Willd). J. Food Composition Anal., 5: 35-68.

Krokida, M.K. and Maroulis, Z.B. (1999). Effect of microwave drying on some quality properties of dehydrated products Drying Technol., 17(3): 449-466.

Lamothe, L.M.; Srichuwong, S.; Reuhs, B.L. and Hamaker, B.R. (2015). Quinoa (Chenopodium quinoa W.) and amaranth (Amaranthus caudatus L.) provide dietary fibres high in pectic substances and xyloglucans. Food Chem., 167: 490-496.

Li, T.; Zhong, J.Z.; Wan, J.; Liu, C.M.; Le, B.Y.; Liu, W. and Fu, G.M., (2013). Effects of micronized okara dietary 
Samah M. Ismael et al.

fiber on cecal microbiota, serum cholesterol and lipid levels in BALB/c mice. Int. J. Food Sci. Nutr., 64: $968 \mathrm{e} 973$.

Liapis, A. and Bruttini, R. (1995). Freeze Drying, In: MUJUMDAR, A.S. Handbook of Industrial Drying. Marcel Dekker. New York.

Lubna, M. and Vidhu, A.B. (2012). Fortification of biscuit with flaxseed: biscuit production and quality evaluation. J. Environ. Sci. Toxicol. Food Technol. (IOSR-JESTFT), 1(5): 6-9.

Margarerita, M.; Vega-Galvez, A.; Lopez, J.; Parada, G.; Sanders, M.; Aranda, M.; Elsa, V. and Karina, D. (2010). Impact of air-drying temperature on nutritional properties, total phenolic content and antioxidant capacity of quinoa seeds (Chenopodium quinoa Willd).Industrial Crops Products, 32: 258-263.

Mastebroek, H.D.; Limburg, H.; Gilles, T. and Marvin, H.J.P. (2000). Occurrence of sapogenins in leaves and seeds of Quinoa ( Chenopodium quinoa Willd). J. Sci. Food Agric., 80:152-156

Matiacevich, S.B.; Castellion, M.L.; Maldonado, S.B. and Buera, M.P. (2006). Water-dependent thermal transitions in quinoa embryos. Thermochimica Acta, 448: 117-122.

Ogungbenle, H.N.; Oshodi, A.A. and Oladimeji, M.O. (2009). The proximate and effect of salt applications on some functional properties of quinoa (Chenopodium quinoa) flour. Pak. J. Nutr. 8 (1): 49 52.

Okpala, L.C. and Okoli, E.C. (2011). Nutritional evaluation of cookies produced from pigeon pea, cocoyam and sorghum flour blends. Afr. J. Biotechnol., 10(3): 433-438.
Padma, I. and Prabhasankar, A. (2013). Fructooligosaccharide- Retention during baking and its influence on biscuit quality. Food Bioscience, 4: 68-80

Pearson, D. (1976). The Chemical Analysis of Food, 1 (Ed). pp. 446- 447. J.A. Churchill, 104 Gloucesterplace, London.

Peleg M. and Bagley, E.B. (1983). Physical Properties of Foods. Westport: CN: AVI Publishers Co.,pp.103-115

Pellegrini, N. and Agostoni, C., (2015). Nutritional aspects of gluten-free products. J. Sci. Food Agric. 95 (12): 2380-2385.

Pomeranz, Y. (1985). Functional properties of food components. New York: Academic Press, Inc.

SAS Program (1996). SAS/STAT User's Guide Release $6.12^{\text {ed }}$. Cary, NC, USA: SAS Inst. Inc.

Singh, P. and Srivastava, S. (2006). Nutritional composition of sixteen new varieties of fingermillet. J. Community Mobilization Sustainable Dev.,1(2): 81-84.

Singh, S. and Rai, T. (1998). Storage studies of whey powder. Beverage and Food World, 25(20): 52-55.

Tang, Y.; Li, X.; Chen, P.X.; Zhang, B., and et al., (2015). Characterisation of fatty acid, carotenoid, tocopherol/tocotrienol compositions and antioxidant activities in seeds of three Chenopodium quinoa Willd genotypes. Food Chem. 174, 502508.

Tilman, J. S.; Colm, M.O.; Denise, M.; Anja, D.; Elke, K. and Arendt, P. (2003). Influence of gluten-free flour mixes and fat powders on the quality of gluten-free biscuits. Eur. Food Res. Technol., 216:369-376.

Ubbor, S.C. and Akobundu, E.N.T. (2009). Quality characteristics of cookies 


\section{Chemical and functional properties of free-gluten biscuit making from corn, quinoa and millet flours}

made from composite flours of watermelon seed, cassava and wheat. Pak. J. Nutrition, 8: 1097-1102.

USDA (2015). National Nutrient Database for Standard Reference Release 27. At:www.ndb.nal.usda.gov/ndb..

Valencia-Chamorro, S.A. (2003). Quinoa. In: Caballero B.: Encyclopedia of Food Science and Nutrition, Vol. 8. Academic Press, Amsterdam: 48954902.

Vega-Gálvez, A.; Miranda, M.; Vergara, J.; Uribe, E.; Puente, L., and Martinez, E.A. (2010). Nutrition facts and functional potential of quinoa (Chenopodium quinoa willd.), an ancient Andean grain: a review. J. Sci. Food Agric., 90(15):2541-2547.

Vijayakumari, J.; Mushtari, B.J.; Shamshad, B. and Sumangala, G. (2003). Sensory attributes of ethnic foods from finger millet. Paper presented at CCSHAU, Hisar. Recent Trends in Millet Processing and Utilization: $7-$ 12.

Vilche, C.; Gely, M. and Santalla, E. (2003). Physical properties of quinoa seeds. Biosystems Engineering, 86: 59-65.
Villa, D.Y.G.; Luigi, R.; Khawla, K.; Maddalena, L. and Luca, R. (2014). Chemical and nutritional characterization of Chenopodium pallidicaule (cañihua) and Chenopodium quinoa (quinoa) seeds. Emir. J. Food Agric., 26(7):609-615.

Wang, S. and Zhu, F. (2016). Formulation and quality attributes of quinoa food products. Food Bioproc. Technol., 91: 49-68

$\mathrm{Wu}, \mathrm{G}$. (2015). Nutritional properties of quinoa. Quinoa: Improvement and Sustainable Production. pp. 193-210. http://dx.doi.org/10.1002/978111862 8041. ch 11.

Yang, X.; Wan, Z.; Perry, L.; Lu, H.; Wang, Q.; Hao, C.; Li, J.; Xie, F.; Yu, J.; Cui, T.; Wang, T.; Li, M., and Ge, Q. H., (2012). Early millet use in northern China. Proc. Nat. Acad. Sci. USA, pp. 1-5.

Zhu, F. and Li, G. (2018). Quinoa starch: Structure, properties, and applications. Carbohydrate polymers, 181: 851-861. 
Samah M. Ismael et al.

الخصائص الكيميانية والوظيفية لبسكويت خالى الجلوتين مصنع من دقيق الذرة و الكينوا و الاخن

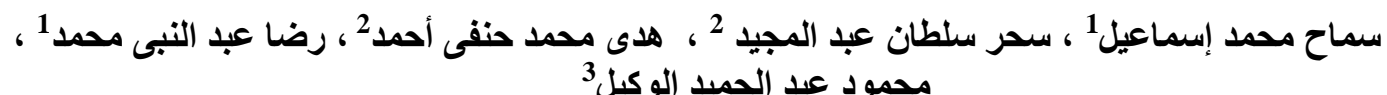

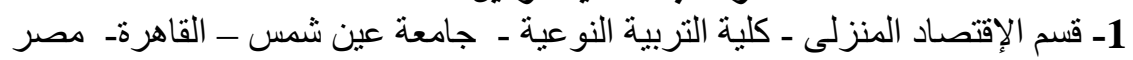

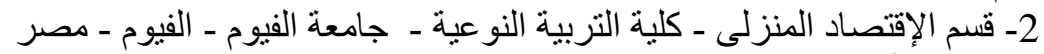

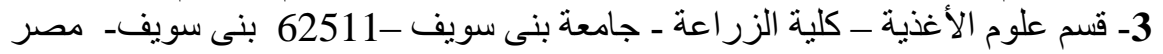

\section{المستخلص}

تهدف هذه الدر اسه إلى تقييم الخصائص الكيميائية و الوظيفية لخلطات مختلفة للبسكويت خالي الجلوتين و علاقتها

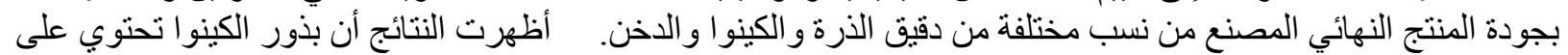

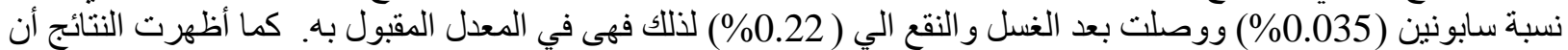

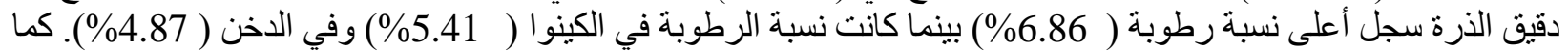

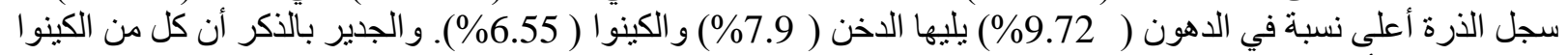

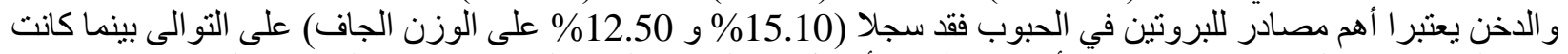

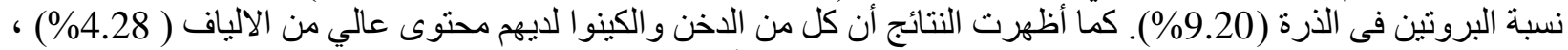

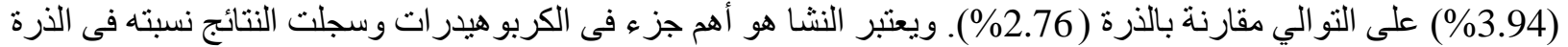

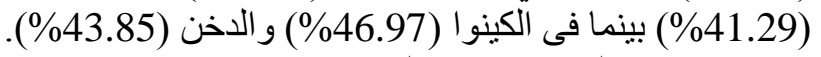

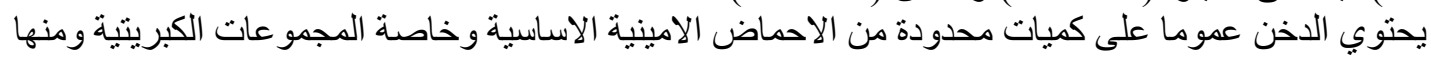

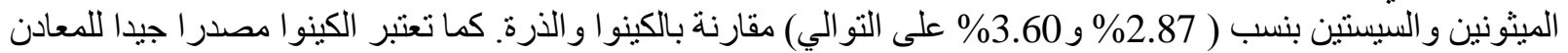

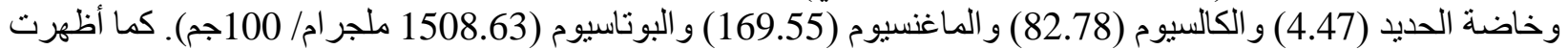

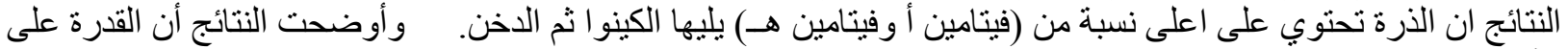

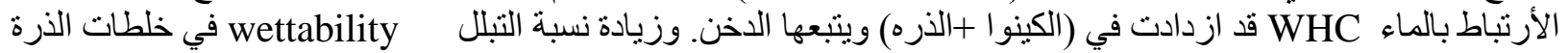

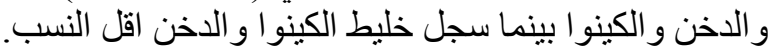

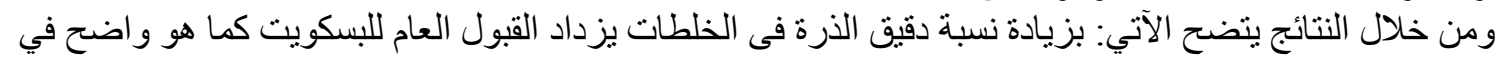

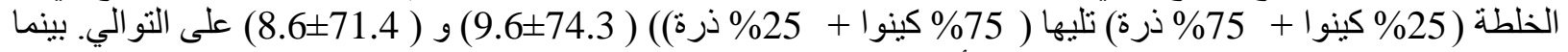

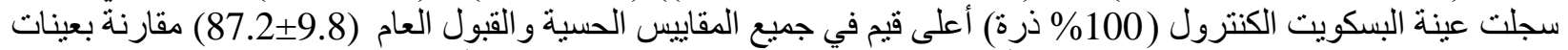

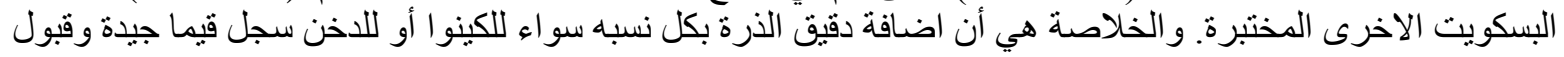
مرضي فى العينات المخلوطة من الحبوب الثناث الثلث معا. الكلمات المفتاحية: الذرة- الكينو اـ الدخنـ البسكويتـ خالي الجلوتينـ الخصائص الوظيفية 